\title{
Comparative study of visual functions in premature pre-school children with and without retinopathy of prematurity
}

\author{
Estudo comparativo das funções visuais em pré-escolares nascidos prematuros com e sem retinopatia \\ da prematuridade
}

Lígia Beatriz Bonottoํ․ Ana Tereza Ramos Moreira², Silvia Chuffi³, Susana Maria Bittencourt Sckudlarek ${ }^{3}$

\begin{abstract}
Purpose: Observe whether there are differences in visual functions among premature infants with treated retinopathy of prematurity (ROP) in relation to preterm infants with ROP and spontaneous regression; and among these two groups with ROP and the control group without ROP.

Methods: Cross-sectional observational no blind study. Premature infants were born between 06/1992-06/2006 and were exam between 06/2009-12/2010; registered in data of Hospital de Olhos Sandalla Amin Ghanem; with gestational age less than or equal to 32 weeks and 1,599 $\mathrm{g}$ born weigh; without ROP and ROP stages II or III, in one of the eyes, with spontaneous regression or with treatment: at least three visits during the selection period at maximum 6 months in the first exam and minimum 4 years of age in reassessment (chronological age) were include. Premature that did not respond or were not located for reassessment and those that did not have conditions to do the exams were exclude. Study's groups: G1- ROP post-treatment; G2-ROP post-spontaneous regression; G3- without ROP (control). Visual function evaluated with visual acuity (VA), contrast sensitivity test (CST), color test (CT), eye movement, stereopsis.

Results: Overall, there were 24 premature infants and 48 eyes. Normal VA: $64.28 \%$ (G1), $87.5 \%$ (G2) and 100\% (G3); Normal CST: 66.67\% (G1), 100\% (G2) and $55.56 \%$ (G3); Normal Ishihara CT: 100\% (G1 and G2) and 86\% (G3); Normal Farnsworth CT: 20\% (G1), 75\% (G2) and 50\% (G3). Normal stereoacuity: 0.00\% (G1); 25\% (G2) and $3.5 \%$ (G3). Strabismus: $37 \%$ (G2), $0.00 \%$ (G1 and G3). The prevalent tendency for lower response in CST and CT between the premature children in group G3 and Farnsworth color test in G1 is a curious result of this work and more study is necessary about these visual functions in older premature children.
\end{abstract}

Conclusion: The visual functions showed no statistically significant difference among the groups studied.

Keywords: Infant, premature; Infant, premature, diseases; Retinopathy of prematurity; Visual acuity; Child, preschool

\section{RESUMO}

Objetivo: Observar se há diferença nas funções visuais entre os prematuros com retinopatia da prematuridade (ROP) pós-tratamento em relação aos prematuros com retinopatia da prematuridade pós-regressão espontânea. Eentre cada um destes grupos com o controle sem ROP.

Métodos: Estudo transversal, observacional, não cego. Incluídas crianças prematuras nascidas entre 06/1992-06/2006eexaminadas entre 06/2009 e12/2010;idadegestacional menorou igual a 32 semanase peso ao nascimento menorouigual a 1.599g; cadastrados no banco de dados do Hospital de Olhos Sandalla Amin Ghanem; com diagnóstico de retinopatia estágio Il ou Ill em pelo menos um dos olhos com regressão espontânea ou por tratamento da ROP e sem retinopatia da prematuridade; mínimo de três consultas no período deseleção; máximo de seis meses deidade cronológica para o primeiroexame no HOSAG; idade cronológica mínima de quatro anos no período da reavaliação. Foram excluídas crianças prematuras que não responderam ou não foram localizados para os exames de reavaliação; e que não ofereciam condições de realização dos exames, por apresentarem comprometimento severo do sistema nervoso central ou sindromes impeditivas. Os prematuros foram divididos em três grupos: G1- prematuros com ROP pós-tratamento; G2-com ROP pós-regressão espontânea; e G3-sem ROP. Função visual avaliada por meio da acuidade visual (AV), teste de sensibilidade ao contrate (TSC), teste de cores (TC), exame de motricidade ocular e estereopsia.

Resultados: Foram examinados 24 prematuros (48 olhos). No grupo $G 1$ formado por 7 prematuros; G2, 8 prematuros e G3, 9 prematuros. AV normal: 64,28\% (G1), 87,5\% (G2) e 100\% (G3); TSC normal: 66,67\% (G1), 100\% (G2) e 55,56\% (G3); TC de Ishihara normal, 100\% (G1 e G2) e 86\% (G3); TC de Farnsworth normal: 20\% (G1), 75\% (G2) e 50\% (G3). Estereopsia normal: 0,00\% (G1), 25\% (G2) e 3,5\% (G3). Estrabismo: 37\% (G2), $0,00 \%$ (G1 e G3). A prevalente tendência de respostas abaixo do esperado no TSC eTC entre os prematuros do grupo G3 exige novos estudos sobre o assunto em prematuros com maior idade.

Conclusão: As funções visuais não apresentaram diferença entre os três grupos de prematuros estudados.

Descritores: Prematuro; Doencas do prematuro; Retinopatia da prematuridade Acuidade visual; Pré-escolar

\section{INTRODUCTION}

For many decades, researchers worldwide have been investigating the causes of retinopathy of prematurity (ROP) and the best method to identify the preterm children that are at risk of developing this disease ${ }^{(1-9)}$. In 2007, one ROP research group in Brazil published the criteria for selecting premature children for examination and ROP treatment, following the assessment of regional characteristics of the disease in Brazil(10).
At present, the analysis of the results of visual functions (VF) of premature infants, i.e., visual acuity, chromatic and contrast discrimination, visual field, stereopsis, and ocular motility, has contributed to unravel the influence of ROP and its treatment on these functions. The effects of developmental conditions during the neonatal period (ROP development, low birth weight, gestational weight and age above the expected for ROP development, presence of neonatal complications, and brain damage) on visual functions have not yet been elucidated ${ }^{(11-16)}$.
Submitted for publication: August 21, 2012

Accepted for publication: October 2, 2013

Study carried out at Hospital de Olhos Sadalla Amin Ghanem, Joinville - Santa Catarina (SC), Brazil. Hospital de Olhos Sadalla Amin Ghanem; UTI Neonatal da UNIMED, Joinville, Santa Catarina, (SC), Brazil.

Universidade Federal do Paraná, PR, Brazil; Hospital de Olhos do Paraná, Curitiba (PR), Brazil.

${ }^{3}$ Hospital de Olhos Sadalla Amin Ghanem, Joinville, Santa Catarina (SC), Brazil.
Funding: No specific financial support was available for this study.

Disclosure of potential conflicts of interest: L.B. Bonotto, None; A.T.R. Moreira, None; S. Chuffi, None; S.M. B. Sckudlarek, None.

Correspondence address: Lígia Beatriz Bonotto. Rua Abdon Batista, 146 - Joinville (SC) - 89201-010 - Brazil - E-mail: ligia@oftalmopediatria.com.br ou ligiaoftalmopediatria@sadalla.com.br Projeto aprovado pelo CEP do Hospital São José, Joinville - S/C. 
The knowledge of the risk factors for VF among premature infants is important for the selection of those who need to be followed up after the neonatal period.

This study aimed to determine possible differences in VF between premature infants at ROP stages II and III and premature infants with spontaneous remission of ROP stages II and III, and compare each of these groups with a group without ROP.

\section{METHODS}

This was an observational, nonblinded, cross-sectional study of the VF responses of premature infants registered in the database of the Hospital de Olhos Sadalla Amin Ghanem (HOSAG). HOSAG database comprised children born before 36 weeks of gestation, according to the definition of prematurity of the World Health Organization $^{(17)}$. The premature infants were selected from the Darcy Vargas Maternity, in Joinville, and from other regions in the state of Santa Catarina, for follow-up after being discharged from the institution where their delivery was conducted. They were classified and treated for ROP according to the International Committees in force during the selection period $(06 / 1992-06 / 2006)^{(7-9)}$. During the re-evaluation period (06/2009 - 12/2010), the infants who fulfilled the criteria of the study underwent eye examinations at HOSAG. The following inclusion criteria were used: premature infants born between 06/1992 and 06/2006, gestational age $\leq 32$ weeks and birth weight $\leq 1,599 \mathrm{~g}$, absence of ROP, occurrence of ROP in stages II or III with spontaneous remission or remission by cryotherapy or laser treatment in at least one eye, minimum of three medical consultations during the selection period, maximum chronological age of 6 months at the time of the first examination at HOSAG (selection period), and minimum chronological age of 4 years during the re-evaluation period. The exclusion criteria were: infants who did not respond or were not followed up for the re-evaluation tests, and those who did not fulfill the criteria for VF assessment because of severe impairment of the central nervous system or syndromes that hindered the performance of the tests.

Infants were divided into three groups: G1, premature infants with ROP, stages II and III, treated by laser or cryotherapy; G2, premature infants with ROP, stages II and III, with spontaneous remission; and $\mathrm{G} 3$, premature infants without ROP (control).

\section{RE-EVALUATION TESTS}

\section{Distance Visual acuity (VA)}

After appropriate optical correction, each eye was separately examined according to a multiethnic pediatric eye disease study (MEPEDS) with preschool children, published in 2009, in which VA better or equal to 20/30 Snellen (or 0.67 in decimal or 0.18 in logMAR) was considered normal(18,19). Infants with VA values lower than normal formed a distinct group and were used for comparison purposes. The letter $E$ on the Snellen chart was used for children aged $<7$ years or illiterate, and letters of the alphabet were used for children aged $>7$ years and literate. Each line had five letters (ETDRS table), and two mistakes were tolerated for the last line visualized on the chart. Visual acuity was assessed at a distance of $4 \mathrm{~m}$. The optotypes were generated using the Opto Magis $2^{\text {nd }}$ generation software and transmitted via a flat screen monitor (Phillips) that complied with the specifications required by the software (15-22-inch liquid-crystal display, backlighting of $200 \mathrm{~cd} / \mathrm{m}^{2}$, and working distance of 3.0-9.5 m). The optotypes were configured by the system software according to the distance used in the test. This system also provided the sensitivity contrast and the Ishihara color tests.

The Teller VA cards test was exceptionally used. Children with neurological and psychomotor development (NPMD) were excluded, particularly those with intellectual or postural and motor stability impairments that precluded the performance of $>2$ of the proposed tests.

\section{Contrast Sensitivity test (CST)}

CST was separately performed on each eye. In this test, gray on white saturation followed a 5\% increment scale until 100\% black was reached. Values of $5 \%-10 \%$ were considered normal (NL), values $>10 \%$ were considered altered (ALT), and the NU category comprised premature infants not submitted to the examination (for statistical purposes). The test was performed at a distance of $4 \mathrm{~m}$, in a dark room, and the only light visible was that from the display. CST was assessed with the optotypes placed two to three lines above the best visual acuity measured (e.g., in VA 20/20, CST was assessed at 20/40).

An optimal contrast test for preschool children does not exist ${ }^{(20,21)}$. This system was selected because the Opto Magis visual acuity equipment allows this test to be applied in any optotype, which is appropriate for use with children.

\section{FARNSWORTH AND ISHIHARA COLOR TESTS}

The Farnsworth D-15 test was performed with natural light and both eyes open. Considering that the children examined were aged $<12$ years, large charts were used (in subnormal vision) to facilitate the test. The software analyzed the results and generated a graph with the score values.

The Ishihara color test was separately applied to each eye and was performed with the child standing at a distance of $4 \mathrm{~m}$ in a dark room. The same software described above generated a sequence of plates with a pattern of colored dots, so that the numbers on each plate could be identified by people without chromatic visual impairments but could not be distinguished by people with abnormal color vision. A total of 38 plates were used, and among them, 13 exhibited a linear pattern that was appropriate for illiterate children, and 25 had a numerical pattern (four of the latter were blind). Children who had difficulty undergoing this test or did not recognize numbers were tested using the Ishihara color test in a booklet format, wherein the plates were shown from a $40-\mathrm{cm}$ distance. Children who did not recognize the numbers were asked to follow with the finger the "little road" in a different color in the "pool of dots."

The children who performed the test without making mistakes were classified as normal (NL), the children who did not perform the test or the test was not conclusive were classified as NU, and the children unable to identify more than three numbers in the Ishihara color test were classified as altered (ALT).

\section{Static Refraction (UNDer Cycloplegia)}

In children aged $<7$ years, one drop of cyclopentolate $1 \%$ and one drop of tropicamide $1 \%$ were instilled in each eye 30 min before the refraction test. In children aged $>7$ years of age, one drop of tropicamide 1\% was instilled in each eye thrice, with an interval of 5 min, and the test was performed 30 min after instillation of the first drop ${ }^{(22)}$. Retinoscopy was performed with trial frame lenses and was confirmed using a skiascopy rack. For statistical analysis, the spherical equivalent was used both for myopia and hyperopia with astigmatism. The spherical equivalent corresponded to the sum of the spherical degree and $50 \%$ of the value of astigmatism. Astigmatism was considered significant when $\geq 1.50$ negative diopters and the percentage difference between the groups was calculated.

\section{MOTILITY TEST}

Eye motility was assessed using the Hirschberg, Krimsky, and the eye cover ocular tests, by observing fixation in the nine positions of gaze. Versions and ductions were tested. The groups were compared for the presence or absence of strabismus. 


\section{StereOPSIS}

Stereoscopic assessment was performed using the Titmus test. The following classification was used: normal (NL): 40 arcseconds, altered (ALT): $>40$ arcseconds, and NRT: those who were unable to perform the Titmus test. To facilitate the calculation of the statistical difference, two distinct groups were considered: the group of premature infants with normal stereopsis (40 arcseconds) and the group with stereopsis above this value.

\section{BINOCULAR INDIRECT OPHTHALMOSCOPY (BIO)}

The BIO test was used for the assessment of the anatomical retinal appearance of premature infants in the three groups. The test was filmed and recorded in DVD.

The pediatric ophthalmologist who performed the BIO, VA, CST, and color tests and the orthoptist who performed the eye motility and stereopsis tests followed up the children at HOSAG after the selection period.

\section{STATISTICAL ANALYSIS}

The Fisher's exact test was used to evaluate the association between the dichotomous variables. The nonparametric Mann-Whitney test was used to compare the quantitative variables between the groups. Values of $\mathrm{p}<0.05$ indicated significance difference. Data were analyzed using the Statistica software, version 8.0.

\section{RESULTS}

The HOSAG database (TASY) included 432 premature infants examined for the risk of developing ROP during the selection period. More details are shown in table 1.

Twenty-four premature infants were selected and divided into three groups: G1-7 premature infants after ROP treatment; G2-8 premature infants after spontaneous ROP remission; and G3-9 premature infants without ROP.

The results of the comparison between the groups with regard to VA, SCT, chromatic sensitivity test, presence of strabismus, and stereopsis are shown in tables 2-7.

Demographic data and the refraction test and indirect ophthalmoscopy data are shown in tables 1 and 2 .

\section{DISCUSSION}

Weight at birth and gestational age above those required to participate in the study were the most important factors for excluding premature infants from the study (Table 1). This reflects the comprehensive approach to the management of ROP in Brazil until the publication of the guidelines for treating ROP in the country, in $2007^{(9)}$. This study was the result of several meetings of the ROP group in Brazil, where studies from various regions of the country were analyzed and discussed ${ }^{(23)}$. Outside Brazil, the definition of the limits of weight and gestational age that indicate risk of ROP and blindness was established by the 1984 and 1987 International Committees(7,8). Other authors observed that the lack of cooperation in answering the repeated calls to participate in the visual assessment tests after the selection period was the factor that most contributed to the cohort reduction (176/505 premature infants) ${ }^{(15)}$. In the present study, this factor was included in the result specified as "other factors" and represented $<10 \%$ of the reduction (Table 1 ).

The good visual functions (FV) results obtained for group G1 were not in line with the findings of a study on VA and strabismus in preschool children published in 1999, wherein the authors observed worse VA among premature infants after ROP treatment ${ }^{(24)}$. Other authors have indicated low birth weight and ROP (mainly stages III and IV) negatively affect the response to VA, static refraction, chromatic and contrast sensitivity tests ${ }^{(13-15)}$.
VA was slightly better in group $G 2$, considering that ROP, gestational age, birth weight, and age group at the time of the re-evaluation examination were similar among groups (Table 2). The high frequency of normal VA among premature infants with postremission ROP and those without ROP was also observed by other researchers ${ }^{(15)}$.

Previous studies suggested that the exclusion of premature infants with neuropsychomotor development problems and the type of treatment performed led to better visual acuity even in premature infants after ROP treatment. Moreover, ROP laser treatment had a positive effect on these results( ${ }^{(24-26)}$. In the present study, only one

Table 1. Premature children selected and examined between $06 / 1992$ and 06/2006 at HOSAG: reasons for excluding subjects from the study on visual function assessment

\begin{tabular}{|c|c|c|}
\hline Motive of exclusion & $\begin{array}{l}\text { Total number } \\
\text { of premature } \\
\text { children } 432 \\
\end{array}$ & $\begin{array}{c}\% \\
100\end{array}$ \\
\hline Gestational weight and age above required & 266 & 61.0 \\
\hline$<3$ visits during the selection period & 39 & 9.0 \\
\hline Impossible to contact & 22 & 5.0 \\
\hline Children aged $<4$ years on re-evaluation & 11 & 2.5 \\
\hline Chronological age $>6$ months on first test & 11 & 2.5 \\
\hline ROP stage higher or lower than required & 11 & 2.5 \\
\hline $\begin{array}{l}\text { Subnormal vision or severe neuropsychomotor } \\
\text { impairment }\end{array}$ & 9 & 2.0 \\
\hline Informed deaths & 3 & 0.6 \\
\hline Children were followed up by another service & 3 & 0.6 \\
\hline Other factors & 33 & 7.6 \\
\hline Total number of premature children per study & 24 & 6.0 \\
\hline
\end{tabular}

Source: HOSAG records (2012)

$\mathrm{ROP}=$ retinopathy of prematurity; Other factors= did not agree to participate in the study or withdrawal from the study.

Table 2. Visual acuity Snellen test (OD and OS): Comparison between premature children after ROP treatment (G1) and premature children after ROP remission (G2) and between each group with ROP and the control group (G3)

\begin{tabular}{lcccc}
\hline Groups & N & $\begin{array}{c}\text { Normal VA } \\
\%\end{array}$ & $\begin{array}{c}\text { Low VA } \\
\%\end{array}$ & p value \\
\hline G1 OD & 7 & 71.43 & 28.57 & 0.569 \\
G2 OD & 8 & 87.50 & 12.50 & \\
G1 OS & $7^{*}$ & 57.14 & 42.84 & 0.282 \\
G2 OS & 8 & 87.50 & 12.50 & \\
G1 OD & 7 & 71.43 & 28.57 & 0.175 \\
G3 OD & 9 & 100.00 & 0.00 & \\
G1 OS & $7^{*}$ & 57.14 & 42.84 & 0.282 \\
G3 OS & 9 & 100.00 & 0.00 & \\
G2 OD & 8 & 87.50 & 12.50 & 0.471 \\
G3 OD & 9 & 100.00 & 0.00 & 0.471 \\
G2 OS & 8 & 87.50 & 12.50 & \\
G3 OS & 9 & 100.00 & 0.00 & \\
\hline
\end{tabular}

Source: HOSAG records (2012)

$\mathrm{OD}=$ right eye; $\mathrm{OS}=$ left eye $\mathrm{VA}=$ visual acuity ${ }^{*}=$ one premature child with amaurosis in the left eye, after 6 years of age, secondary to total late retinal detachment. Normal= visual acuity considered as normal (20/30 or better).

Nonparametric Mann-Whitney test for $\mathrm{p}<0.05$ 
premature infant in group G1 underwent cryotherapy; this fact and the exclusion of premature infants with severe development impairment may have contributed to good VA performance in the three groups under study.

With regard to contrast visual sensitivity, the group of premature infants after ROP treatment exhibited lower contrast sensitivity than the remaining groups (Table 3). On the other hand, in 2001 the Cryotherapy for ROP Cooperative Group observed a better contrast sensitivity among treated premature infants ${ }^{(20)}$. The difficulty in correlating low contrast sensitivity with $\mathrm{ROP}$ severity was also observed by other authors ${ }^{(15,21)}$.

The result obtained for group G2 was slightly better than that obtained for group G3 (without ROP). This unexpected finding may be explained by the early age of the premature children in group $\mathrm{G} 3$ (mean age of 5 years, whereas the mean age of the remaining groups was 6 years), and was not in line with the findings of the Cryotherapy for ROP Cooperative Group, who studied 10-year-old children in 2001. According to a 1981 study conducted with preschool children and their mothers, the factor that affected the responses was the difference in associative knowledge and not necessarily the age difference between the two groups ${ }^{(27)}$.

Table 3. Contrast sensitivity test (OD and OS): Comparison between premature infants after ROP treatment (G1) and after ROP remission (G2) and between each group with ROP and the control group (G3)

\begin{tabular}{llccc}
\hline Groups & $\mathbf{N}$ & $\begin{array}{c}\text { NL TSC } \\
\%\end{array}$ & $\begin{array}{c}\text { ALT TSC } \\
\%\end{array}$ & p value \\
\hline G1 OD & $6^{*}$ & 66.67 & 33.33 & 0.192 \\
G2 OD & $7^{* * *}$ & 100.00 & 0.00 & \\
G1 OS & $5^{* *}$ & 60.00 & 40.00 & 0.523 \\
G2 OS & $7^{* * *}$ & 85.71 & 14.29 & \\
G1 OD & 6 & 66.67 & 33.33 & 1 \\
G3 OD & 9 & 55.56 & 44.44 & 1 \\
G1 OS & 5 & 60.00 & 40.00 & \\
G3 OS & 9 & 55.56 & 44.44 & 0.088 \\
G2 OD & 7 & 100.00 & 0.00 & \\
G3 OD & 9 & 55.56 & 44.44 & 0.308 \\
G2 OS & 7 & 85.71 & 14.29 & \\
G3 OS & 9 & 55.56 & 44.44 & \\
\hline
\end{tabular}

Source: HOSAG records (2012).

$\mathrm{OD}=$ right eye; $\mathrm{OS}=$ left eye; $\mathrm{NLTSC}=$ normal contrast sensitivity test; $\mathrm{ALTTSC}=$ altered contrast sensitivity test; $\mathrm{G} 1\left(^{*}\right)$ : one premature infant in $\mathrm{G} 1$ did not undergo the test on both eyes; $\left.1{ }^{* *}\right)$ : another premature infant in G1 did not undergo the CST test on the left eye (total retinal detachment); $\mathrm{G} 2\left(^{* * *}\right)$ : one premature infant in $\mathrm{G} 2$ did not undergo the CST test. Nonparametric Mann-Whitney test for $\mathrm{p}<0.05$

Table 4. Ishihara color test: Comparison between groups $\mathrm{G} 1$ and G3 (OU) and G2 and G3 (OU)

\begin{tabular}{lcccc}
\hline Groups & N & $\begin{array}{c}\text { CT IHNL } \\
\%\end{array}$ & $\begin{array}{c}\text { CT IHALT } \\
\%\end{array}$ & p value \\
\hline G1 OU & 5 & 100.00 & 0.00 & 1 \\
G3 OU & 7 & 85.71 & 14.29 & 1 \\
G2 OU & 6 & 100.00 & 0.00 & \\
G3 OS & 7 & 85.71 & 14.29 & \\
\hline
\end{tabular}

Source: HOSAG records (2012).

$\mathrm{OU}=$ both eyes: $\mathrm{OS}=$ left eye: $\mathrm{CT} \| \mathrm{HNL}=$ normal Ishihara color test: $\mathrm{CT} \| \mathrm{HALT}=$ altered Ishihara color test; $\mathrm{N}=$ number of premature infants who underwent the test in each group (total premature infants per group: $\mathrm{G} 1=7, \mathrm{G} 2=8$, and $\mathrm{G} 3=9$ )

Nonparametric Mann-Whitney test for $\mathrm{p}<0.05$
In group G1, the different CST results obtained for the right and left eyes may be explained by the difference in disease severity between the eyes.

Other reasons for excluding G1 and G2 groups from the test were the difficulty in communicating verbally, overall developmental and learning disability (inability to understand the test), and total retinal detachment in one eye (Table 3).

The three groups under study exhibited good performance in the Ishihara color test (Table 4). However, there was a large percentage of unfavorable responses in G1 using the Farnsworth D-15 test.

Table 5. Farnsworth D-15 AO color test: comparison between groups G1 and G2

\begin{tabular}{lcccc}
\hline Groups & N & $\begin{array}{c}\text { CT FW-D15 NL } \\
\%\end{array}$ & $\begin{array}{c}\text { CT FW-D15 ALT } \\
\%\end{array}$ & p value \\
\hline G1 OU & 5 & 20.00 & 80.00 & 0.206 \\
G2 OU & 4 & 75.00 & 25.00 & \\
G1 OU & 5 & 20.00 & 80.00 & 0.524 \\
G3 OU & 4 & 50.00 & 50.00 & \\
G2 OU & 4 & 75.00 & 25.00 & 1 \\
G3 OU & 4 & 50.00 & 50.00 & \\
\hline
\end{tabular}

Source: HOSAG records (2012)

OU= both eyes; CT FW-D15 NL= normal Farnsworth D-15 color test; CT FW-D15 ALT= altered Farnsworth D-15 color test. $\mathrm{N}=$ number of premature infants that underwent the test in each group (total premature infants per group: $\mathrm{G} 1=7, \mathrm{G} 2=8, \mathrm{G} 3=9$ ).

Nonparametric Mann-Whitney test for $\mathrm{p}<0.05$.

Table 6. Strabismus: Comparison between premature infants after ROP treatment (G1) and after remission of ROP Stages II and III (G2)

\begin{tabular}{lcccc}
\hline Groups & N & $\begin{array}{c}\text { Strabismus } \\
\text { Yes (\%) }\end{array}$ & $\begin{array}{c}\text { Strabismus } \\
\text { No (\%) }\end{array}$ & p value \\
\hline G1 OU & 7 & 0.00 & 100.00 & 0.200 \\
G2 OU & 8 & 37.50 & 62.50 & \\
G1 OU & 7 & 0.00 & 100.00 & - \\
G3 OU & 9 & 0.00 & 100.00 & 0.082 \\
G2 OU & 8 & 37.50 & 62.50 & \\
G3 OU & 9 & 0.00 & 100.00 &
\end{tabular}

Source: HOSAG records (2012).

$\mathrm{OU}=$ both eyes.

Nonparametric Mann-Whitney test for $p<0.05$.

Table 7. Stereopsis: Comparison between premature infants with after treatment RO (G1) and after remission of ROP Stages II and III (G2)

\begin{tabular}{lcccc}
\hline Groups & N & $\begin{array}{c}\text { Stereopsis } \\
\text { NL (\%) }\end{array}$ & $\begin{array}{c}\text { Stereopsis } \\
\text { ALT (\%) }\end{array}$ & p value \\
\hline G1 OU & 7 & 0.00 & 100.00 & p: 0.467 \\
G2 OU & 8 & 25.00 & 75.00 & \\
G1 OU & 7 & 0.00 & 100.00 & p: 0.200 \\
G3 OU* & 8 & 37.50 & 62.50 & \\
G2 OU & 8 & 25.00 & 75.00 & P:1 \\
G3 OU & 8 & 37.50 & 62.50 &
\end{tabular}

Source: HOSAG records (2012).

$\mathrm{OU}=$ both eyes; $\mathrm{NL}=$ normal Titmus test $\mathrm{ALT}=$ altered,$>40$ arcseconds; $\mathrm{NRT}=$ those who were unable to perform the Titmus test. ${ }^{*}=$ one premature infant did not undergo the Titmus test.

Nonparametric Mann-Whitney test for $\mathrm{p}<0.05$. 
Chart 1. Demographic data for the three groups of premature preschool children classified into three groups of retinopathy of prematurity (G1, G2, and G3), considering the variables gender, chronological age on re-evaluation (CRA), gestational age (GA), birth weight (BW), and number of medical consultations between the selection and re-evaluation periods

\begin{tabular}{|c|c|c|c|c|c|c|c|c|c|c|c|}
\hline \multirow[t]{2}{*}{ Groups } & \multirow[b]{2}{*}{$\mathbf{N}$} & \multicolumn{2}{|c|}{ Gender } & \multicolumn{2}{|c|}{$\begin{array}{c}\text { CRA } \\
\text { (years) }\end{array}$} & \multicolumn{2}{|c|}{$\begin{array}{c}\text { GA } \\
\text { (weeks) }\end{array}$} & \multicolumn{2}{|c|}{$\begin{array}{c}\text { WB } \\
\text { (grams) }\end{array}$} & \multicolumn{2}{|c|}{$\begin{array}{c}\text { Number of } \\
\text { Visits }\end{array}$} \\
\hline & & M (\%) & F (\%) & mean & DP & mean & DP & mean & DP & mean & DP \\
\hline G 1 & 7 & 71 & 29 & 6.1 & 1.6 & 28.1 & 1.9 & 1.015 & 123.5 & 24.4 & 20.5 \\
\hline G 2 & 8 & 25 & 75 & 6.5 & 1.9 & 27.2 & 1.6 & 963.7 & 123.0 & 19.8 & 13.9 \\
\hline G 3 & 9 & 78 & 22 & 5.1 & 0.9 & 28.4 & 2.5 & 991.1 & 258.4 & 9.7 & 4.2 \\
\hline
\end{tabular}

$\mathrm{G} 1=$ group after treatment of ROP stages $\mathrm{II}$ and III; $\mathrm{G} 2=$ groups at ROP stages II and III in remission; $\mathrm{G} 3=$ group without $\mathrm{ROP} ; \mathrm{M}=$ male; $\mathrm{F}=\mathrm{female;} \mathrm{CRA}=$ chronological age on re-evaluation; $\mathrm{GA}=$ gestational age; $\mathrm{BW}=$ birth weight. $\mathrm{SD}=$ standard deviation; $\mathrm{N}=$ total number.

Chart 2. Distribution of static refraction and VA data in groups G1, G2, and G3

\begin{tabular}{|c|c|c|c|c|c|c|c|c|}
\hline & \multicolumn{4}{|c|}{ Right eye } & \multicolumn{4}{|c|}{ Left eye } \\
\hline & Spherical & Cylinder & Axis & Acuity & Spherical & Cylinder & Axis & Acuity \\
\hline \multicolumn{9}{|c|}{ G1-laser } \\
\hline 1 & +0.50 & -0.50 & 180 & $20 / 20$ & 0.00 & -0.50 & 180 & $20 / 20$ \\
\hline 2 & +2.00 & 0.00 & 0 & $20 / 20$ & +1.50 & 0.00 & 0 & $20 / 30$ \\
\hline 3 & -5.50 & -3.00 & 105 & $20 / 30$ & -4.25 & 0.00 & 0 & $20 / 25$ \\
\hline 4 & -4.25 & -0.75 & 125 & $20 / 60$ & 0.00 & 0.00 & 0 & $20 / 20$ \\
\hline 5 & +0.50 & -1.75 & 180 & $20 / 30$ & -0.50 & -3.00 & 180 & $20 / 40$ \\
\hline 6 & -6.50 & -2.00 & 170 & $20 / 30$ & * & & & $* *$ \\
\hline 7 & -2.75 & -0.50 & 180 & $20 / 63$ & -2.75 & -0.50 & 180 & $20 / 63$ \\
\hline \multicolumn{9}{|c|}{ G2- without laser } \\
\hline 8 & +4.50 & -1.25 & 10 & $20 / 20$ & +4.75 & -1.50 & 170 & $20 / 20$ \\
\hline 9 & +2.25 & 0.00 & 0 & $20 / 20$ & +2.50 & 0.00 & 0 & $20 / 20$ \\
\hline 10 & +2.00 & -0.50 & 165 & $20 / 20$ & +2.25 & 0.00 & 0 & $20 / 20$ \\
\hline 11 & +2.00 & -0.50 & 180 & $20 / 20$ & +2.00 & -0.50 & 165 & $20 / 20$ \\
\hline 12 & +0.25 & -0.25 & 90 & $20 / 20$ & +0.25 & 0.00 & 0 & $20 / 20$ \\
\hline 13 & +1.50 & -0.25 & 90 & $20 / 20$ & +1.50 & -0.25 & 5 & $20 / 20$ \\
\hline 14 & +1.75 & -1.25 & 15 & $20 / 50$ & +1.75 & -1.50 & 180 & $20 / 50$ \\
\hline 15 & +2.00 & -0.50 & 90 & $20 / 20$ & +1.50 & 0.00 & 0 & $20 / 20$ \\
\hline \multicolumn{9}{|c|}{ G3- without ROP } \\
\hline 16 & -0.25 & 0.00 & 0 & $20 / 20$ & 0.00 & 0.00 & 0 & $20 / 20$ \\
\hline 17 & +2.50 & 0.00 & 0 & $20 / 20$ & +2.50 & 0.00 & 0 & $20 / 20$ \\
\hline 18 & +1.50 & -0.75 & 180 & $20 / 20$ & +1.50 & -1.00 & 180 & $20 / 20$ \\
\hline 19 & +1.00 & -0.50 & 180 & $20 / 20$ & +1.00 & -0.50 & 180 & $20 / 20$ \\
\hline 20 & +1.75 & 0.00 & 0 & $20 / 20$ & +2.00 & -0.50 & 180 & $20 / 20$ \\
\hline 21 & +3.00 & -0.25 & 90 & $20 / 20$ & +2.50 & 0.00 & 0 & $20 / 20$ \\
\hline 22 & +1.50 & 0.00 & 0 & $20 / 20$ & +1.50 & -0.50 & 90 & $20 / 20$ \\
\hline 23 & +1.00 & 0.00 & 0 & $20 / 20$ & +1.00 & 0.00 & 0 & $20 / 20$ \\
\hline 24 & +1.25 & -0.50 & 170 & $20 / 20$ & +1.50 & 0.00 & 0 & $20 / 20$ \\
\hline
\end{tabular}

This percentage was significantly higher than that observed by the CRYO-ROP study group ( $80 \%$ in G1 vs. 2.8\% in the CRYO-ROP study). According to these authors, this deficiency was related to low visual acuity and not to possible alterations inherent to prematurity itself or to ROP severity ${ }^{(28)}$. However, in the present study, $64.28 \%$ premature infants in group G1 exhibited good visual acuity.
In the three groups under study, the reason for excluding premature infants from this test was their difficulty in understanding the color test (TC), which was in agreement with the findings of other authors who observed that, after excluding the children unable to perform the color test, the responses of premature children were very similar to those of full-term children ${ }^{(29)}$. 
The absence of cases of strabismus in group G1 contradicted the findings of other authors in similar studies, which indicated the occurrence of strabismus in $26 \%-44 \%$ of premature infants after ROP treatment, and this proportion was dependent on the type of treatment (laser or cryotherapy) $)^{(14,24,25,30)}$. In the present study, the study sample was small and the possibility that the exclusion criteria selected premature infants without strabismus in group G1 cannot be discarded. The ideal would be to assess the presence of strabismus in premature children excluded for other reasons; however, such evaluation was not the aim of this study.

A 37\% incidence of convergent strabismus in group G2 was in accordance with the results obtained by other authors, who found a similar frequency and a higher percentage of convergent strabismus among premature infants after spontaneous ROP remission ${ }^{(24,31)}$.

Of the four infants in G2 with neuropsychomotor development problems, three presented with strabismus. Therefore, the proportion of infants with neurological problems was relevant in this group and may explain the higher percentage of strabismus in the group with spontaneous remission, as was also observed by other authors ${ }^{(11,14,24,30,31)}$

Stereopsis was present in 57\% the premature infants in group G1. A similar result was observed in a study published in 2005, wherein $66.6 \%$ premature infants with ROP treated with laser exhibited stereopsis (24). However, no premature infants exhibited normal stereopsis. Strabismus was not among the causes of the low performance of $\mathrm{G} 1$ with regard to stereopsis. On the other hand, low unilateral or bilateral VA was responsible for this result. The lower stereoscopic resolution observed among premature infants after ROP treatment was in line with other studies that associated stereoscopic resolution with ROP severity ${ }^{(14,30)}$. In group $G 2$, the nonrecognition of the Titmus test and the suppression caused by strabismus represented $37 \%$ of the $75 \%$ change in this test. In addition, age contributed to the low frequency of normal stereopsis among the groups G2 and G3.

In this study there was no difference between premature children after ROP treatment and those after spontaneous ROP remission with regard to the visual functions assessed. In addition, there was no difference between the groups with ROP and the control (Tables 2-7).

The limitations of the present study include sample size, which may have contributed to the nonsignificant differences between the groups. Therefore, additional studies from other institutions that study ROP in Brazil are necessary.

The lack of standardization of the chromatic and contrast sensitivity tests precludes the comparison of results across studies. Further studies using tests performed in computers and high-definition monitors may help solve these limitations.

The results of VA and the presence of strabismus in the groups with ROP highlight the risks of low vision and amblyopia and suggest the need for close follow-up of preschool and school children.

\section{CONCLUSION}

There was no significant difference in visual functions between premature infants after ROP treatment and those after spontaneous remission, and between premature infants with ROP and without ROP.

\section{REFERENCES}

1. Terry TL. Extreme prematurity and fibroblastic over-growth of persistent vascular sheath behind each crystalline lens. Am J Ophthalmol. 1942;25:203-4.

2. Owens WC, Owens EU. Retrolental fibroplasia in premature infants. Am J Ophthalmol. 1949;32(1):1-21.

3. Reese AB. Persistence and hyperplasia of primary vitreous; retrolental fibroplasia; two entities. Arch Ophthal. 1949;41(5):527-52.

4. Kinsey VE. Retrolental fibroplasia; cooperative study of retrolental fibroplasia and the use of oxygen. AMA Arch Ophthalmol. 1956;56(4):481-543.

5. Kinsey VE, Arnold HJ, Kalina RE, Stern L, Stahlman M, Odell G, et al. PaO2 levels and retrolental fibroplasia: a report of the cooperative study. Pediatrics. 1977;60(5):655-68.
6. Flynn JT, Bancalari E, Bachynski BN, Buckley EB, Bawol R, Goldberg R, et al. Retinopathy of prematurity. Diagnosis, severity, and natural history. Ophthalmology. 1987;94(6): $620-9$

7. An international classification of retinopathy of prematurity. The Committee for the Classification of Retinopathy of Prematurity. Arch Ophthalmol. 1984;102(8):1130-4.

8. An international classification of retinopathy of prematurity. II. The classification of retinal detachment. The International Committee for the Classification of the Late Stages of Retinopathy of Prematurity. Arch Ophthalmol. 1987;105(7):906-12. Erratum in: Arch Ophthalmol 1987;105(11):1498.

9. International Committee for the Classification of Retinopathy of Prematurity. The International Classification of Retinopathy of Prematurity revisited. Arch Ophthalmol. 2005:123(7):991-9. Review.

10. Zin A, Florêncio T, Fortes Filho JB, Nakanami CR, Gianini N, Graziano RM, Moraes $\mathrm{N}$; Brazilian Society of Pediatrics, Brazilian Council of Ophthalmology and Brazilian Society of Pediatric Ophthalmology. [Brazilian guidelines proposal for screening and treatment of retinopathy of prematurity (ROP)]. Arq Bras Oftalmol. 2007;70(5):875-83. Portuguese.

11. Holmström G, Larsson E. Long-term follow-up of visual functions in prematurely born children-a prospective population-based study up to 10 years of age. J AAPOS. 2008;12(2):157-62.

12. Mirabella G, Kjaer PK, Norcia AM, Good WV, Madan A. Visual development in very low birth weight infants. Pediatr Res. 2006;60(4):435-9.

13. O'Connor AR, Stephenson TJ, Johnson A, Tobin MJ, Ratib S, Moseley M, et al. Visual function in low birthweight children. Br J Ophthalmol. 2004;88(9):1149-53.

14. O'Connor AR, Fielder AR. Visual outcomes and perinatal adversity. Semin Fetal Neonatal Med. 2007;12(5):408-14.

15. O'Connor AR, Stephenson T, Johnson A, Tobin MJ, Moseley MJ, Ratib S, et al. Long-term ophthalmic outcome of low birth weight children with and without retinopathy of prematurity. Pediatrics. 2002;109(1):12-8.

16. Robaei D, Kifley A, Gole GA, Mitchell P. The impact of modest prematurity on visual function at age 6 years: findings from a population-based study. Arch Ophthalmol. 2006;124(6):871-7.

17. World Health Organization. Weekly epidemiological record relevé épidémiologique hebdomaire. Wkly Epidem Rec. 1984;59:205-12

18. Pan Y, Tarczy-Hornoch K, Cotter SA, Wen G, Borchert MS, Azen SP, Varma R; Multi-Ethnic Pediatric Eye Disease Study Group. Visual acuity norms in pre-school children: the Multi-Ethnic Pediatric Eye Disease Study. Optom Vis Sci. 2009;86(6):607-12.

19. Holladay J. Proper method for calculating average visual acuity. J Refract Surg. 1997; 13:388-91.

20. Cryotherapy for Retinopathy of Prematurity Cooperative Group. Contrast sensitivity at age 10 years in children who had threshold retinopathy of prematurity. Arch Ophthalmol. 2001;119(8):1129-33.

21. Larsson $E$, Rydberg A, Holmström G. Contrast sensitivity in 10 year old preterm and full term children: a population based study. Br J Ophthalmol. 2006;90(1):87-90.

22. Bicas HE. Sociedade Brasileira de Oftalmologia Pediátrica. Prescrição de óculos na infância [Internet]. São Paulo: Sociedade Brasileira de Oftalmologia Pediátrica; s.d. p. 1-21. [citado 2014 Jan 17]. Disponível em: http://www.cbo.com.br/cbo/sociedades/ pediatria/artigos/prescricoes_oculos_infancia.pdf

23. Sociedade Brasileira de Oftalmologia Pediátrica. Projeto ROP Brasil: na prevenção da cegueira por retinopatia da prematuridade [Internet]. São Paulo:CBO; 2006. [citado 2014 Jan 17]. Disponível em: http://dnanet.dna.com.br/sbop/site/interna. asp?campo $=119 \&$ secao_id $=6$

24. Holmström G, el Azazi M, Kugelberg U. Ophthalmological follow up of preterm infants: a population based, prospective study of visual acuity and strabismus. $\mathrm{Br} J$ Ophthalmol. 1999:83(2):143-50.

25. Ospina LH, Lyons CJ, Matsuba C, Jan J, McCormick AQ. Argon laser photocoagulation for retinopathy of prematurity: long-term outcome. Eye (Lond). 2005;19(11):1213-8.

26. Sahni J, Subhedar NV, Clark D. Treated threshold stage 3 versus spontaneously regressed subthreshold stage 3 retinopathy of prematurity: a study of motility, refractive, and anatomical outcomes at 6 months and 36 months. Br J Ophthalmol. 2005:89(2):154-9.

27. Atkinson J, French J, Braddick O. Contrast sensitivity function of preschool children. Br J Ophthalmol. 1981;65(8):525-9.

28. Dobson V, Quinn GE, Abramov I, Hardy RJ, Tung B, Siatkowski RM, et al. Color vision measured with pseudoisochromatic plates at five-and-a-half years in eyes of children from the CRYO-ROP study. Invest Ophthalmol Vis Sci. 1996:37(12):2467-74.

29. Jackson TL, Ong GL, McIndoe MA, Ripley LG. Monocular chromatic contrast threshold and achromatic contrast sensitivity in children born prematurely. Am J Ophthalmol. 2003:136(4):710-9.

30. VanderVeen DK, Coats DK, Dobson V, Fredrick D, Gordon RA, Hardy RJ, Neely DE, Palmer EA, Steidl SM, Tung B, Good WV; Early Treatment for Retinopathy of Prematurity Cooperative Group. Prevalence and course of strabismus in the first year of life for infants with prethreshold retinopathy of prematurity: findings from the Early Treatment for Retinopathy of Prematurity study. Arch Ophthalmol. 2006;124(6):766-73.

31. Bremer DL, Palmer EA, Fellows RR, Baker JD, Hardy RJ, Tung B, et al. Strabismus in premature infants in the first year of life. Cryotherapy for Retinopathy of Prematurity Cooperative Group. Arch Ophthalmol. 1998;116(3):329-33. 